\title{
Authority of Prosecutor as the Executor of Judge's Decision Stating That the Evidence Is Confiscated for the State; Criminal Act in the Excise Field
}

\author{
Corinna Patricia; Yoserwan; A Irzal Rias \\ Faculty of Law, Andalas University, Indonesia \\ http://dx.doi.org/10.18415/ijmmu.v8i9.2950
}

\begin{abstract}
The objectives of the current study are: 1) to identify and analyze the authority of prosecutor as the executor of judge's decision on the spoils resulting from criminal act of excise, 2) to find out and analyze the arrangements regarding the coordination of the prosecutor as the executor with the Director of Enforcement and Investigation/ Head of the Regional Office of the Directorate General of Customs and Excise related to the execution of the judge's decision stating that the evidence is confiscated for the state in criminal act in the excise field. This study applies a qualitative approach and uses secondary and primary data as support. The results of the study show that: (1) the executive authority of the prosecutor to carry out court decisions that have permanent legal force in criminal cases is regulated in Articles 270 to 276 of the Criminal Procedure Code. The provisions of Article 270 of the Criminal Procedure Code are in line with the provisions described in Article 54 paragraph (1) of Law No. 48 of 2009 concerning Judicial Powers that the implementation of court decisions in criminal cases is carried out by prosecutor. Then, the implementation of court decisions in cases of criminal acts in the excise field still refers to the Criminal Procedure Code because the Excise Law does not specifically determine the party authorized to carry out the execution of state booty in excise crimes, (2) the execution of judge's decision stating evidence confiscated for the state in a criminal act in the excise field does not include regulations regarding the coordination of the prosecutor as executor with the Director of Enforcement/Head of Regional Office of the Directorate of Customs and Excise Enforcement and Investigation.
\end{abstract}

Keywords: Authority of Prosecutor; Execution of Evidence; Directorate General of Customs and Excise

\section{Introduction}

Article 1 paragraph (3) of the 1945 Constitution affirms that Indonesia is a state of law. In other words, Indonesia prioritizes the rule of law in order to maintain truth, justice, and guard against irresponsible power. ${ }^{1}$ As a state of law mentioned above, Indonesia of course follows the basic principles of the rule of law to realize an orderly, just, prosperous and peaceful nation and state life as the state philosophy contained in Pancasila which is still recognized and maintained together until now. (Shidarta, 2004).

\footnotetext{
${ }^{1}$ People's Consultative Assembly of the Republic of Indonesia, 2010, Correctional Guidelines for the 1945 Constitution of the Republic of Indonesia (according to the Order of Chapters, Articles and Paragraphs), Secretary General of the People's Consultative Assembly of the Republic of Indonesia, Jakarta, page 46.
} 
In the implementation of life as a nation and state, the state must ensure that every citizen gets all his rights so that prosperity can be achieved. The achievement of the welfare and prosperity of the Indonesian people in a fair and equitable manner is realized by carrying out national development, especially in the economic sector. The existence of excise duty has a major influence in maintaining economic stability and national security. The basis is that excise is one of the various forms of state treasury income. The cash obtained from excise duty is then used for the development of the country in order to realize the prosperity and welfare of all citizens. The majority of state revenues to date have been derived from tax revenues.

The rampant circulation of illegal objects cannot be denied. We can see it through the news about the actions taken by the Customs and Excise officials against the circulation of illegal objects in various regions in Indonesia. (Pratama, 2017). Throughout 2020, the Directorate of Customs and Excise in the Eastern Sumatra Region has taken 650 actions against violations in the customs and excise sector. The Bengkalis Customs and Excise thwarted the smuggling of goods without customs documents, which included hundreds of smuggled mobile phones together with hundreds of cans of illegal liquor with a total value of hundreds of millions of rupiah and confiscated 80,300 illegal cigarettes without excise stamps (Primansyah et al, 2021). What is meant is objects that do not have legality, are declared forbidden to be circulated or traded by law, and have problems with import and export licensing (Prayatna, 2019). The circulation of illegal goods has an impact on economic development because it will kill the domestic industry. In the end, it will also have an impact on the implementation of national development because it will reduce state revenues from taxes.

Recognizing the complexity of the problem of excise crimes among crises in various sectors and the potential factual threats, including the effects of these crimes, excise crimes can be grouped into state problems that must be seriously resolved through strict and transparent procedures involving all state resources. especially the government and law enforcement.

In terms of eradicating criminal acts in the excise sector, the involvement of law enforcement consists of investigators, public prosecutors, and judges. The final determinant in eradicating criminal acts in the excise sector is the judge. However, the judge does not have the authority to act actively apart from the realm of the case as proposed in the trial by the prosecutor. Regarding criminal justice, the duties and authorities are regulated in Law no. 8 of 1981 while the prosecutor's office is regulated in Law No. 16 of 2004. Each of the laws and regulations as mentioned is a change from the previous regulations.

Execution is the final stage of case resolution in the criminal justice system. After the decision has been made by the judge, the evidence is then executed as ordered by the court's decision as regulated in Article 46 paragraph (2) of the Criminal Procedure Code. ${ }^{2}$ The evidence can be returned to the appointed party, confiscated for the state or confiscated so that it is later destroyed or remains confiscated which is then used in other trial evidence. If an object is decided to be confiscated by the state, the execution of the object is carried out through an auction stage, the results of which are then included in state revenue. ${ }^{3}$

Furthermore, by the Director of Enforcement and Investigation or the Head of Regional Office within the Directorate General of Customs and Excise, it is declared as state property and will be administered and stockpiled at a certain location called the Customs Hoarding Place or other place as determined by the Directorate General of Customs and Excise. ${ }^{4}$

\footnotetext{
${ }^{2}$ Article 46 paragraph (2) of the Criminal Procedure Code states that if a case has been decided, the object declared to be confiscated is returned to the party as stated in the decision, unless the ruling states that the object is declared confiscated for the state, or destroyed so that it cannot be reused.

${ }^{3}$ Confiscated goods for the purposes of the criminal justice process is called the confiscated objects (Government Regulation No. 58 of 2010). The confiscated objects are part of the non-tax income in Government Regulation no. 22 of 1997, among others: (1) income from the sale of confiscated objects; (2) income from the sale of confiscated proceeds; (3) income from compensation and criminal acts of corruption; (4) income from court fees; (5) and others, in the form of found money, auction results of found objects as well as proceeds from the sale of an object; (6) evidence not taken by the rightful; (7) income from fines.

${ }^{4}$ Ibid. Article 4.
} 
Referring to the elaboration above, the implementation of court decisions related to the execution of state confiscated objects in criminal acts in the excise sector, the ruling stated that evidence confiscated for the state cannot be auctioned by the prosecutor in collaboration with the State Wealth Service and Auction Office. However, the prosecutor as the executor submits it to the Director of Enforcement and Investigation or the Head of the Regional Office within the Directorate General of Customs and Excise. This provision means that it will lengthen the bureaucracy which will gradually lead to a decrease in economic value and even loss of value due to damage to the object. Thus, it cannot be used as one of the various state revenues.

\section{Research Method}

This is a normative legal research conducted through various sources of literature and other secondary data sources. (Soekanto, 2006). The determination of the type of research is based on the framework of thinking that this research aims to conduct analysis and study related to the position of the prosecutor as an executor in excise crimes and arrangements related to the execution of the judge's decision stating that the evidence was confiscated for the state in a criminal act in the field of excise.

\section{Results and Discussion}

\section{Authority of the Prosecutor's Office in Executing Confiscated Goods}

Prosecutors and public prosecutors are generally held by one individual. However, there are different definitions between prosecutors and public prosecutors in legal regulations. Article 1 point 6 of the Criminal Procedure Code states that prosecutors are officials mandated by law to act as public prosecutors and realize court decisions with permanent legal force. Meanwhile, public prosecutors are prosecutors who are mandated by law to carry out prosecutions and realize judges' decisions. Thus, the main function of the public prosecutor is to carry out prosecutions or delegate cases to a district court that has the competence as regulated in positive law with a demand that the submission of the case be examined and then decided by the judge in the trial. (Wisnubroto, 2014)

Article 1 point 1 of the Prosecutor's Law states that the prosecutor is a functional official who is mandated by the law to act as a public prosecutor and the executor of court decisions with permanent legal force or other authority as mandated by law. Referring to the regulation, the function of the prosecutor's office, in addition to carrying out prosecutions at the stage of law enforcement and justice, also carries out various other functions as mandated by law. The prosecutor's function includes preventive and repressive functions in the criminal sector and state attorneys in the civil and state administration sectors.

In the field of crime, the prosecutor's office as an element/sub-system in criminal justice, has the authority described in Article 14 of the Criminal Procedure Code which essentially includes:

a. receive and examine the investigation case files from investigators or assistant investigators;

b. conduct pre-prosecution if there are deficiencies in the investigation by observing the mandate of Article 110 paragraph (3) and paragraph (4) and provide instructions with the aim of improving the investigation of the investigator;

c. request an extension of detention, carry out the execution of detention or further detention and/or change the status of the detainee after the transfer of the case by the investigator;

d. draw up an indictment;

e. delegate cases to court;

f. notify the defendant regarding the day and time of the trial along with a summons to the defendant or to the witness to attend the trial as determined;

g. carry out prosecutions;

h. declare the closure of the case in the interest of law; 
i. carry out other actions within the scope of responsibilities and functions as a public prosecutor referring to the laws and regulations;

j. carry out the judge's decision.

Based on this elaboration, the task and function of the public prosecutor is to continue the examination process that has been completed at the investigation stage to the prosecution stage until carrying out the judge's decision which has obtained permanent legal force. The role of the prosecutor as the executor of decisions that have permanent legal force is regulated in Article 1 point 6 and Article 270 of the Criminal Procedure Code and Article 30 paragraph (1) letter b of the Prosecutor Law which determines in the criminal sector. The Prosecutor's Office has the obligation and function to make judges' decisions and court decisions that have permanent legal force. Therefore, the implementation of the decision must be carried out by the prosecutor, not other officials.

In realizing the court's decision, as explained in the Elucidation of Article 30 paragraph (1) letter b of the Prosecutor's Law, the Prosecutor's Office is obliged to observe the various values of living law in society and humanity with reference to Pancasila while remaining firm in every action. Implementing court decisions is a realization of obligations and functions of controlling the implementation of the death penalty as well as court decisions on confiscated objects that have been or are about to be confiscated which are then auctioned.

The prosecutor, as the executor of court decisions with permanent legal force, is regulated in Article 270 of the Criminal Procedure Code and then also regulated in Article 54 paragraph (1) of the Law on Judicial Powers that the execution of court decisions in criminal cases is carried out by an attorney. Thus, we can understand that prosecutors are officials who carry out the task of executing court decisions. Therefore, in realizing court decisions, prosecutors are required to have knowledge and understanding regarding the procedures for executing court decisions. In order for the execution to run smoothly, the Attorney General's Letter No. B-235/E/3/1994 and the Decree of the Attorney General of the Republic of Indonesia No. KEP-518/A/JA/11/2001 is issued as a technical guide for the execution of court decisions with permanent legal force. (Rusly, 2007)

In the event of a criminal execution of confiscation of evidence, the prosecutor informs the state auction office so that for a duration of three months the auction of the goods is carried out where the proceeds of the sale are then given to the state treasury on behalf of the prosecutor (Article 273 paragraph (3) of the Criminal Procedure Code). The auction can be extended with a maximum duration of 3 months. In addition to confiscation, according to Article 46 paragraph (2) of the Criminal Procedure Code, evidence can also be terminated and then crushed or destroyed so that it cannot be used anymore.

If the decision states the imposition of criminal compensation, as stated in Article 99 of the Criminal Procedure Code (compensation to victims of offenses or other parties who are harmed), its implementation is carried out by referring to the procedure for civil decisions carried out by the bailiff. The prosecutor's execution can also end in an auction, which in essence, evidence is found objects, confiscated objects, which can then be used as state confiscated objects related to criminal cases.

Seized objects are objects which, according to a court decision with permanent legal force, are declared confiscated for the state (Chalik, 2015). Confiscated objects are evidence or tools that can then be auctioned off if the court has decided and the decision has permanent legal force. Confiscated objects can also be accounted for. If confiscated objects are to be auctioned, it must be done simultaneously and cannot be done separately unless there are urgent conditions as described in point 9 of the Attorney General's Circular Letter No: SE-03/B/B.5/8/1988 concerning the settlement of confiscated objects. In general, confiscated objects in a court decision may not be auctioned separately except in urgent conditions. (Pratama, 2017) 
The settlement of state confiscated objects is regulated in Article 3 of the Attorney General's Decree No: KEP-089/J.A/8/1988 which is carried out through auctions at the State Auction Office or used for state needs, social needs, or crushed until they are destroyed and cannot be used anymore. The execution period is regulated in Article 4, which is a maximum of 4 months from a court decision that has permanent legal force. The period of time is binding and it is the responsibility of the attorney general to comply with it. Referring to Article 273 paragraph (3) and paragraph (4) of the Criminal Procedure Code, it is stated that:

1. Article 273 Paragraph (3) "If the court's decision stipulates that the evidence is confiscated for the state, other than the exception to article 46, the prosecutor authorizes the object to the State Auction Office and within 3 (three) months to sell it at auction, the proceeds of which are deposited into the state treasury for and on behalf of the prosecutor."

2. Article 273 Paragraph (4) "The period as referred to in paragraph (3) may be extended for a maximum of one month."

So that Article 273 paragraph 3 of the Criminal Procedure Code is not misapplied by judges in making decisions, SEMA No. 24 of 1983 was issued which stated that the ruling only needed to include the words "confiscated for the state" and did not need to include the words "for sale at auction".

\section{Arrangement for Coordination of the Prosecutor as Executor with the Director of Enforcement and Investigation/Head of the Regional Office of the Directorate General of Customs and Excise related to the Execution of Confiscated Goods in Criminal Act in the Excise Sector}

In order to carry out responsibilities, an organization requires a coordination between the leadership and its members. Through effective communication, clear information delivery, and good human resource management, every element of the organization will be able to work well in line with its responsibilities. Coordination is the stage of integrating achievements and activities in separate units in order to efficiently realize organizational goals (Yahya, 2006). Referring to Manullang's opinion, coordination is an effort to regulate the activities of various organizational elements so that they lead to a certain direction so that each element can contribute their optimally and in harmony in achieving organizational goals holistically. (Manullang, 2012)

Coordination can be established in various ways. The four main ways to maintain coordination include (Manullang, 2012):

a. Hold an official meeting between each element that requires coordination. The meeting held deliberation and discussion of each element with the hope that each of these elements can work in harmony in achieving the goals of the organization.

b. Appoint a person, a team, or a coordinating committee who is exclusively responsible for carrying out various coordination activities, for instance, providing explanations and directions to each element.

c. Prepare a guidebook that contains details of the responsibilities of each unit in the organization. The book is given to each unit to be used as a reference in carrying out activities.

d. Holding meetings between superiors and subordinates regarding the delivery of directions, consultations, and input.

The various ways are carried out with the main hope of avoiding conflicts. Through these various ways, harmony, cooperation, unity of action, and ultimate goals are expected to be realized. Regarding law enforcement, coordination is also needed in terms of implementing court decisions that have permanent legal force. The agency authorized or entitled to carry out court decisions/issuance especially in settling the spoils is the prosecutor's office. The explanation of the second paragraph of Article 30 letter b of the Prosecutor's Law states that: "Implementing court decisions includes also carrying out duties and authorities, controlling the execution of the death penalty and court decisions on confiscated goods that have been and will be subsequently auctioned off." 
In the implementation of the crime of confiscation of evidence based on Articles 12 to 14 of the Attorney General's Decree no. KEP-089/JA/8/1988, the Head of the High Prosecutor's Office or the Head of the District Attorney's Office or the Head of the District Prosecutor's Office who has control of the confiscated goods shall receive an import ban and a prohibition on circulation to immediately report to the Junior Attorney General who has the authority to resolve confiscated goods for further settlement. It is intended so that the Attorney General of the Republic of Indonesia can determine the benefits of a confiscated item for the needs of the state, society, or even destroy it so that it can no longer be used by obeying the mandate of positive law.

Referring to this elaboration, the execution of the prosecutor's office is essentially the implementation of decisions related to objects previously used as evidence, both found objects or confiscated objects which are later declared confiscated for the state in criminal cases, without specifying the type of criminal case.

However, in criminal acts in the field of excise, the settlement of confiscated evidence for the state is regulated in Regulation of the Minister of Finance of the Republic of Indonesia No. 39/PMK.04/2014. The regulation describes the settlement of goods subject to excise duty or other goods confiscated for the state or controlled by the state as mandated by the Excise Law and the Regulation of the Minister of Finance. The settlement is delegated to Customs and Excise in accordance with Article 3 of the Regulation of the Minister of Finance, which essentially states that:

a. The Director of Enforcement and Investigation, the Head of the Regional Office, as well as the Head of the Office that carries out the handling of criminal cases in the field of excise shall receive the delegation of excisable objects or other objects that have been decided to be confiscated by the state from the prosecutor as the executor of the court's decision.

b. Minutes of handover are prepared for the handover activities as referred to in point a.

c. Excisable goods and other goods as stated above shall be declared to be state property.

Referring to the above regulation, the Prosecutor shall hand over excisable goods or other objects declared confiscated for the state to the Director of Investigation and Investigation, Head of Regional Office, or Head of Office that carries out handling of criminal cases in the excise sector.

The Director of Enforcement and Investigation or the Head of the Regional Office within the Directorate General of Customs and Excise declares it as a state property and will be administered and stockpiled at a certain location called the Customs Hoarding Place or other place as determined by the Directorate General of Customs and Excise.

Then, related to the allocation of state property as mandated in Article 12 paragraph (1) of the Regulation of the Minister of Finance No. 39/PMK.04/2014 concerning Procedures for Settlement of Excisable Goods and Other Goods Seized by the State or Controlled by the State in Article 2 paragraph (1) of Law no. 39 of 2007 concerning Amendments to Law No. 11 of 1995 concerning Excise, among others: Certain objects that have traits or characteristics:

a. It requires consumption control

b. It requires circulation control

c. Its use carries a bad risk to society or the environment; or

d. Its use requires the imposition of a state levy for the sake of justice and balance which is subject to excise under this Law.

What is meant by other objects in the crime of excise refers to Article 1 point 3 Regulation of the Minister of Finance no. 13/PMK.06/2018, namely various objects that have a direct correlation with objects that are subject to excise, for instance transportation facilities that are used to transport excisable objects, equipment or machines that are used to produce excisable goods. 
This study refers to the results of research on various court decisions in criminal cases in the excise sector, namely the Decision of the Kudus District Court No. 95/Pid.Sus/2018/PN.Kds and the Decision of the Kudus District Court No. 169/Pid.Sus/2019/PN.Kds. Banjarmasin District Court Decision No. 569/Pid.Sus/2018/PN.Bjm. Referring to the results of research from 3 court decisions related to cases of excise crimes, the prosecutor's office will coordinate with customs in the completion of the execution of confiscated goods related to criminal acts in the excise sector if the evidence confiscated for the state is objects taxable. The Prosecutor as the executor will hand over the confiscated goods to the Customs and Excise Supervision and Service Office, Intermediate Excise Type, as referred to in Article 3 of the Regulation of the Minister of Finance No. 39/PMK.04/2014. However, if the confiscated goods are not included in the qualification of excisable goods, but other goods as referred to in Article 1 paragraph (1) Regulation of the Minister of Finance No. 39/PMK.04/2014, the prosecutor as the executor does not hand over the confiscated goods to the Customs and Excise Supervision and Service Office, Intermediate Excise Type, as referred to in Article 3 of the Regulation of the Minister of Finance of the Republic of Indonesia No: 39/PMK.04/2014. In this case, the prosecutor's office will coordinate with the State Property and Auction Service Office. Therefore, there is no coordination arrangement for the prosecutor as the executor with the Director of Enforcement and Investigation/Head of the Regional Office of the Directorate General of Customs and Excise regarding the execution of confiscated goods in criminal acts in the excise sector.

\section{Conclusion}

The prosecutor's executorial authority to realize a criminal court decision that has permanent legal force is an authority obtained by way of attribution, namely the authority obtained by the prosecutor directly from the editorial article of the legislation. In this case, it is regulated in Article 270 to Article 276 of the Criminal Procedure Code. The provisions of Article 270 of the Criminal Procedure Code are in line with the provisions described in Article 54 paragraph (1) of Law no. 48 of 2009 that prosecutors carry out the execution of decisions in criminal cases. The execution of court decisions in criminal cases in the excise sector still refers to the Criminal Procedure Code because the Excise Law does not specifically determine the party authorized in carrying out the execution of court decisions that have obtained permanent legal force and also the execution of court decisions on state spoils in acts tax penalty.

The execution of the judge's decision stating that evidence was confiscated for the state in a criminal act in the field of excise did not include arrangements regarding the coordination of the prosecutor as the executor with the Director of Enforcement/Head of Regional Office of the Directorate of Customs and Excise Enforcement and Investigation. In executing the court's decision on state confiscated goods from criminal acts in the excise sector, the ruling stated that if the evidence is confiscated for the state against excisable goods, the prosecutor as the executor submits it to the Director of Enforcement/Head of Regional Office of the Directorate of Customs and Excise Enforcement and Investigation. However, in carrying out the execution of the court decision, the prosecutor as the executor does not submit evidence confiscated for the state against other goods in the crime of excise to the Director of Enforcement/Head of the Regional Office of the Directorate of Customs and Excise Enforcement and Investigation, as stipulated in the Regulation of the Minister of Finance of the Republic of Indonesia No. 39/PMK.04/2014 but it was submitted to the Office of the State Assets and Auction Service for auction.

\section{References}

Chalik, M. (2015). Pengelolaan benda sitaan dan barang rampasan negara di rumah penyimpanan benda sitaan negara klas 1 banda aceh. ETD Unsyiah.

Manullang, M. (2012). Dasar-Dasar Manajemen (Cetakan keduapuluh dua). Gadjah Mada University Press. Yogyakarta.

Pratama, M. A. (2017). Maraknya Penyelundupan Barang Ilegal di Wilayah Perbatasan dan Pengaruhnya Terhadap Perekonomian Indonesia [PhD Thesis]. PERPUSTAKAAN. 
Prayatna, H. (2019). Peran Penyidik Bea dan Cukai dalam Pemberantasan Tindak Pidana Penyelundupan Bawang Merah (Studi pada Kantor Wilayah Direktorat Jenderal Bea Cukai Sumatera Utara) [PhD Thesis]. Universitas Medan Area.

Primansyah, E., Nisyak, H., \& Murti, K. (2021). Strategi humas kantor wilayah direktorat jenderal bea dan cukai sumatera bagian timur dalam mensosialisaikan program "gempur rokok ilegal" $[\mathrm{PhD}$ Thesis]. Sriwijaya University.

Rusly, M. (2007). Hukum Acara Pidana Kontemporer, C, Bandung. Citra Aditya Bakti.

Shidarta, B. A. (2004). Kajian Kefilsafatan tentang Negara Hukum. Jurnal Jentera, 7.

Soekanto, S. (2006). Pengantar penelitian hukum. Penerbit Universitas Indonesia (UI-Press).

Wisnubroto, A. (2014). Praktek Persidangan Pidana. Universitas Atma Jaya.

Yahya, Y. (2006). Pengantar Manajemen. Graha Ilmu.

\section{Copyrights}

Copyright for this article is retained by the author(s), with first publication rights granted to the journal.

This is an open-access article distributed under the terms and conditions of the Creative Commons Attribution license (http://creativecommons.org/licenses/by/4.0/). 